\title{
A NOTE ON PERRY'S RECONSIDERATION OF \\ MACROECONOMIC EVIDENCE FROM NEW ZEALAND *
}

\author{
Paul Dalziel \\ Professor of Economics \\ Commerce Division, Lincoln University \\ P.O. Box 84, Lincoln 7647, NEW ZEALAND \\ dalzielp@lincoln.ac.nz \\ David Peetz \\ Professor of Employment Relations, \\ Griffith Business School, Griffith University, \\ Brisbane, QLD 4111, AUSTRALIA \\ d.peetz@griffith.edu.au
}

\begin{abstract}
Perry in this journal draws on two new sources to challenge claims by Dalziel (2002) and Peetz (2005) about relatively weak labour productivity growth in New Zealand after the introduction of its Employment Contracts Act (ECA) in 1991. While new data raise further research questions, they do not overturn our original conclusions. Whether the ECA contributed to higher labour input growth compared to Australia, it failed to improve labour productivity growth.
\end{abstract}

JEL Classification: J24, O47

Keywords: Labour productivity, Australia, New Zealand

(1 May 2008)

Australian Economic Review, 41 (4), 389-393.

* We thank Len Perry for helpful feedback on an earlier draft, and Antony Ede at Statistics New Zealand for assistance with obtaining data. We are grateful to Mark Wooden and two referees for useful suggestions. 


\section{A NOTE ON PERRY'S RECONSIDERATION OF MACROECONOMIC EVIDENCE FROM NEW ZEALAND}

\section{Introduction}

Debates about Australia's Workplace Relations Amendment (Work Choices) Act 2005 rekindled interest in whether New Zealand's similarly depicted Employment Contracts Act 1991 (ECA) produced any positive impact on aggregate labour productivity in that country. Dalziel (2002, p. 42) concluded that 'the introduction of the ECA appears to have marked the end of a long period of strong comparability between New Zealand and Australian labour productivity growth, to New Zealand's great disadvantage'. Peetz (2005) included Dalziel's analysis in the evidence for his conclusion that 'there is no inherent relationship between the form of coverage [individual contracting or collective bargaining] and growth in productivity' (p. 49). More recently, Perry (2006) argues two new data sources for comparing Australian and New Zealand economic performance do not support our claims. Here we reply that the new data sources raise further research questions, but do not overturn our original conclusions.

\section{The Total Economy Database}

The first new source is the Total Economy Database provided by The Conference Board and Groningen Growth and Development Centre (TCB/GGDC), which presents time series on key variables for 124 countries. ${ }^{1}$ Early values for New Zealand annual hours in that dataset are created using Australian trends. This makes them unsuitable for comparing the two countries, but an alternative is available based on a series of average weekly labour hours 
published by the New Zealand Department of Labour from 1957 to 1986 (Fletcher, 1990). This alternate series has been used in Figure 1, which otherwises uses the TCB/GGDC data to depict labour productivity in New Zealand and Australia. The figure also includes a third line, showing New Zealand's labour productivity after 1978, rebased to equal Australia's value in 1978. The impact of using the Department of Labour data to calculate New Zealand total labour hours turns out to be negligible, and so four points made by Perry (2006) are immediately apparent in Figure 1:

1. New Zealand experienced lower labour productivity growth than Australia after the introduction of the ECA in 1991.

2. The fall in New Zealand's relative performance after 1991 is better explained by an exceptional performance by Australia (following, inter alia, a shift from awards to collective 'enterprise' bargaining) than by a deterioration in New Zealand's labour productivity growth.

3. New Zealand also experienced periods of lower average labour productivity growth than Australia prior to 1991.

4. If the two series are rebased to a common value in 1978 then (after dipping during the centralised Accord) Australia’s relative labour productivity passed New Zealand's in the midst of the ECA period rather than in 1991 as per the analysis of Dalziel (2002). 
Figure 1 Labour Productivity, Australia and New Zealand: TCB/GGDC Estimated EKS US\$ GDP per Total Hours Worked, 1960-2005

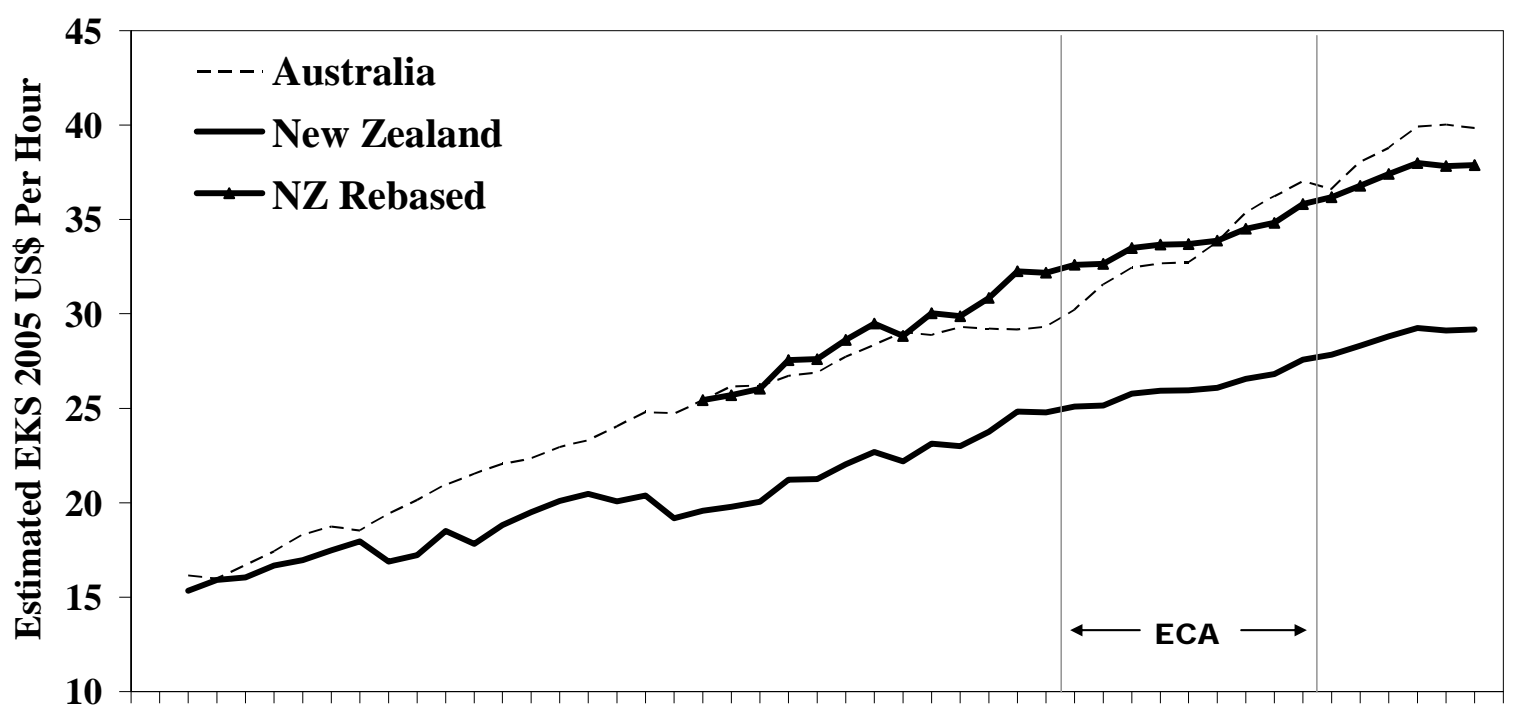

$\begin{array}{lllllllllllllllllllllll}60 & 62 & 64 & 66 & 68 & 70 & 72 & 74 & 76 & 78 & 80 & 82 & 84 & 86 & 88 & 90 & 92 & 94 & 96 & 98 & 00 & 02 & 04\end{array}$ Calendar Years

Source: TCB/GGDC, Total Economy Database, September 2006, <http://www.ggdc.net>, and Labour and Employment Gazette, New Zealand Department of Labour, various issues.

Point 1 confirms Dalziel's (2002) original conclusion and the importance of the related research question: why was New Zealand's labour productivity growth performance so much worse than Australia's in the 1990s, despite the introduction of its Employment Contracts Act in April 1991? Point 2 suggests the answer is found in an exceptional performance by Australia over that period, but this answer confirms the conclusion of Peetz (2005) and others in the 'Work Choices' debate: if individual bargaining and individual contracts really are the key to labour productivity growth, how did Australia manage to produce very high labour productivity growth in the 1990s at a time when its trans-Tasman neighbour continued to struggle under the ECA?

Point 3 needs an important caveat. Between 1960 and 1991, the poor performance of New Zealand's productivity growth compared to Australia can be explained by two discrete 
collapses associated with international trade shocks: in 1967, when labour productivity in New Zealand fell by 6.0 per cent; and in 1977, when it fell by 5.9 per cent. These figures are 2.8 standard deviations below the mean productivity growth rate for New Zealand over the 45-year period, and there are no other years with comparable departures from mean in either direction for either country. ${ }^{2}$ Policy-induced rigidities (including labour laws and the countercyclical expansion of public sector employment) presumably contributed to the domestic impact of the two shocks, but we cannot deduce from these aggregate data that New Zealand's industrial relations system was creating a persistent drag on labour productivity growth. Indeed, in the period after the second shock, 1977 to 1991, New Zealand's labour productivity growth averaged 1.9 per cent per annum, compared to 1.4 per cent in Australia.

Point 4 invites analysis of why new data have produced this slightly different pattern. The explanation is in Figure 2. In the period common to both studies (1978-1998), total hours in Australia grew faster than the number of full-time equivalent employees, while in New Zealand the reverse was true. This means that New Zealand's productivity performance was not as bad, and Australia's not as good, as Dalziel (2002) obtained when using full-time equivalent employees as the denominator. Nevertheless, Figure 2 confirms Dalziel's main point that New Zealand's reforms involved a significant economic sacrifice: between 1984 and 1991, total hours in New Zealand fell by 7.5 per cent (and did not return to their 1984 level until 1994) while they grew in Australia by 17.1 per cent. There was a sharp turning point in 1991; between 1991 and 2005, total hours grew by 36.7 per cent in New Zealand, compared to 26.4 per cent in Australia. The ECA may have played a part in this turnaround, but there is no evidence here of any closing of the labour productivity gap between the two countries. 
Figure 2 Comparison of Full Time Equivalent Employees and Total Hours: Australia and New Zealand, 1978-1998

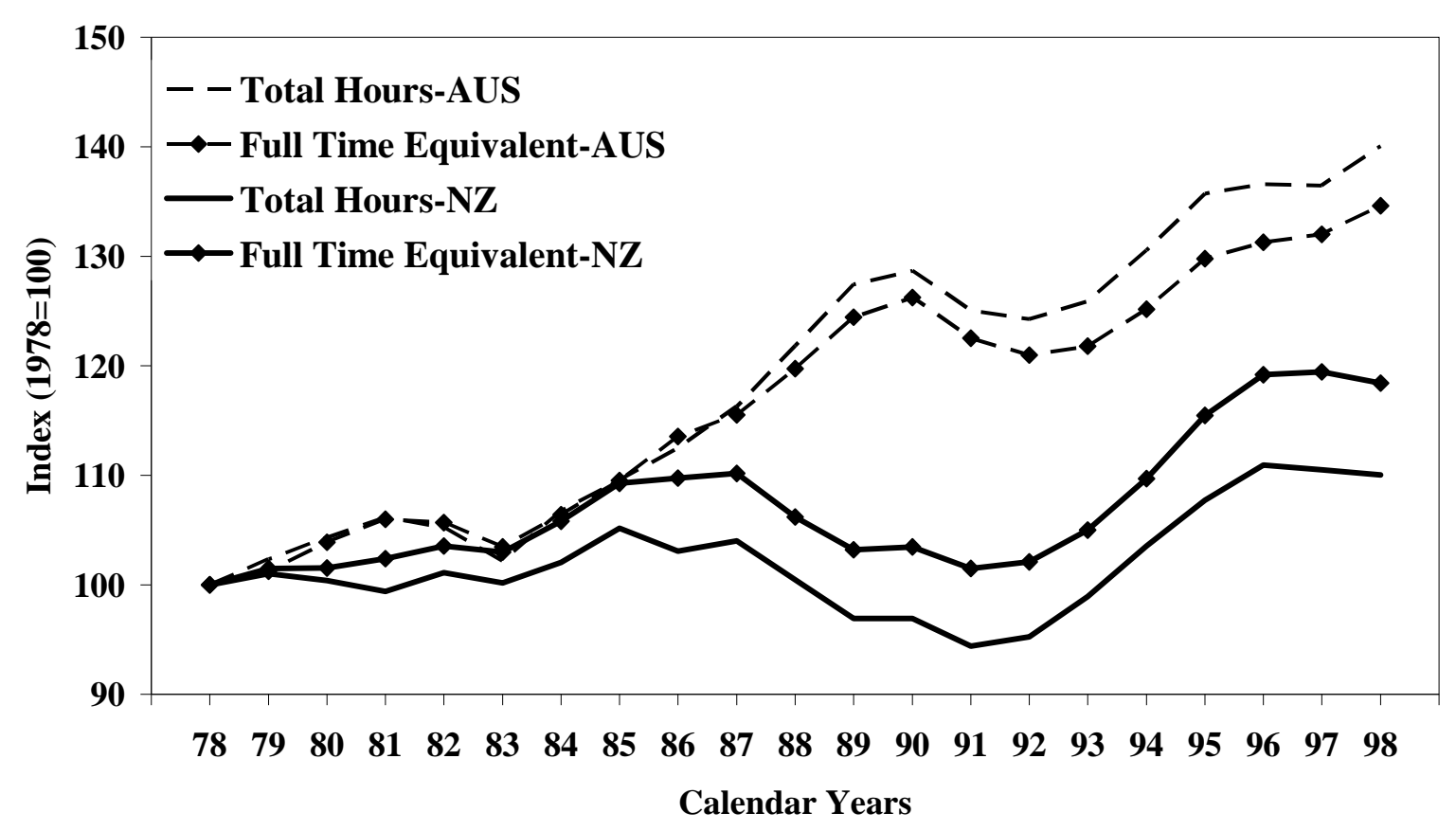

Source: Calculated from Figure 1 and Dalziel (2002).

\section{The Measured Productivity Data}

The second new data source is a Statistics New Zealand (2002) analysis that reports parity in the labour productivity growth of the measured ('market') sectors of Australia and New Zealand between 1987/88 and 2004/05. Perry bases his claims on that study's full period results, 1987/88-2004/05, but for clear comparisons we need to focus on the period after 1990/91 (the year during which the ECA was introduced), as shown in Figure 3. Output (and labour input) grew in the measured sectors of the two economies at similar rates between 1990/91 and 2004/05. As Australia introduced its Workplace Relations Act from 1997, these similarities illustrate Peetz’s (2005, p. 49) conclusion that ‘there is no inherent relationship between the form of coverage and growth in productivity’.

Perry suggests 'given that Australian labour productivity growth was relatively high during these years, it is very likely that New Zealand's labour productivity growth was also 
relatively high during the ECA years' (p. 371). Perry’s brave conjecture cannot be tested until the New Zealand series is extended to earlier years, but in the meantime the evidence is not supportive: the data in Figure 3 imply that labour productivity growth between 1987/88 and 1990/91 was 12.7 per cent in New Zealand, but only 5.9 per cent in Australia. It is possible that New Zealand was engaged in labour productivity catch-up in the final years of collective bargaining, which did not continue after the shift to individual contracting in 1991.

The results might also be reconciled by divergent trends in the countries' non-measured sectors. Drew (2007, p. 27) calculates that the Statistics New Zealand data imply that 'on average, [labour] productivity growth in the non-measured sector (NMS) in New Zealand has been negative at around minus 1.5 percent per annum (and negative in most years) while the rate in Australia has been positive at around 0.7 percent'. A poor performance in the nonmeasured sector is important for the total economy because the hours paid in New Zealand's non-measured sector grew almost twice as fast as in its measured sector between 1992/93 and 2004/05 (44.2 per cent versus 22.9 per cent; Statistics New Zealand, 2006, Figure 2). Whether it reflects measurement issues (see, for example, Douglas, 2006), or deeper problems such as slower growth in wages or the capital/labour ratio in New Zealand, are matters warranting further research. 
Figure 3 Output and Labour in the Measured Sector: Australia and New Zealand, 1987/88-2004/05

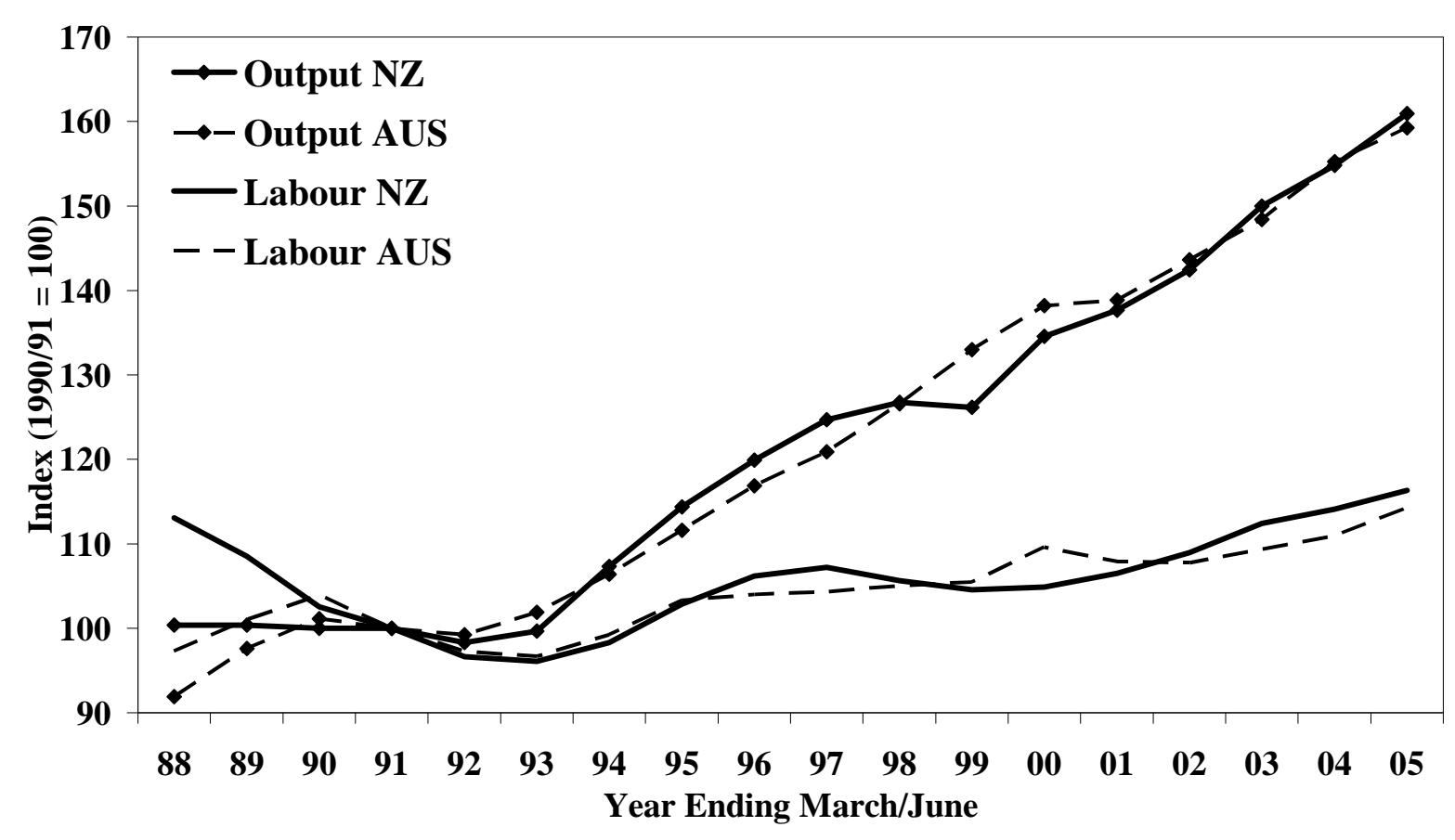

Source: Australian Bureau of Statistics and Statistics New Zealand

\section{Concluding remarks}

Perry has made an interesting contribution but it would be unfortunate if it led to a view that New Zealand's productivity has been strong in recent times. The TCB/GGDC Total Economy Database has also been analysed by David Skilling, Chief Executive of the business-funded New Zealand Institute, who notes that the entire trans-Tasman per capita income gap can be explained by the difference in the two countries’ labour productivity. Skilling comments:

About two thirds of New Zealand's economic growth generated since 1990 has been due to growth in hours worked, as unemployment has reduced and labour force participation has risen. Only one third has been due to labour productivity growth. New Zealand's labour productivity growth rate of $1.0 \%$ over the past 15 years is in the bottom quartile of OECD countries. Indeed, New Zealand has only maintained its relative income position in the OECD since 1990 by working more hours to almost exactly offset its declining relative labour productivity level. This is not a sustainable way to proceed. [2007, pp. 1-2] 
New Zealand's move in 1991 from an industrial relations system based on collective bargaining to one based on individual contracting may have contributed to that increase in labour inputs over the last 15 years, but it did not help address New Zealand's long-standing problems with labour productivity growth relative to other countries in the OECD. 


\section{Endnotes}

1 See TCB/GGDC (2006). The database can be downloaded without charge from http://www.ggdc.net.

2 The closest is a New Zealand cycle in 1969 and 1970 which saw a positive difference of 2.2 standard deviations immediately followed by a negative difference of 1.9 standard deviations; otherwise, all observations for both countries lie within 1.8 standard deviations of their respective means. 


\section{References}

Dalziel, P. 2002, 'New Zealand's economic reforms: an assessment', Review of Political Economy, vol. 14, pp. 31-46.

Douglas, J. 2006, 'Measurement of public sector output and productivity', Policy Perspectives Paper 09/06, New Zealand Treasury, Wellington.

Drew, A. 2007, 'New Zealand's productivity performance and prospects', Reserve Bank of New Zealand Bulletin, vol. 70(1), pp. 19-33.

Fletcher, M. 1990, 'Growth phases in the New Zealand economy since 1965', Occasional Paper 1990/1, New Zealand Department of Labour, Wellington.

Peetz, D. 2005, 'Hollow shells: the alleged link between individual contracting and productivity growth', Journal of Australian Political Economy, no. 56, pp. 32-54.

Perry, L. J. 2006, 'Do workplace contracts harm labour productivity growth? A reconsideration of the macroeconomic evidence from New Zealand', Australian Economic Review, vol. 39, pp. 359-75.

Skilling, D. 2007, 'The New Zealand economy: prospects and priorities', Boardroom: The Journal of the Institute of Directors in New Zealand Inc, February, pp. 1-2.

Statistics New Zealand 2006, 'Productivity statistics: 1988-2005', Statistics New Zealand, Wellington, viewed 9 December 2006, <http://www.stats.govt.nz/products-andservices/info-releases/productivity-statistics.htm>.

TCB/GGDC 2006, 'Total Economy Database, September 2006', The Conference Board and Groningen Growth and Development Centre, viewed 1 December 2006, $<$ http://www.ggdc.net/dseries/totecon.shtml>. 